\title{
REVIEW OF DECISIONS OF STATE COURTS OVER STATE MATTERS BY THE FEDERAL SUPREME COURT
}

\author{
Muradu Abdo*
}

\section{Introduction}

A decision of any court in Ethiopia today can be reviewed by the Cassation Division of the Federal Supreme Court (hereinafter the Cassation Division) if it manifests a prima facie case for basic error of law and if it is a final decision and is filed within the time limit ${ }^{1}$. This article examines the scope of the Cassation Division's power, i.e., whether there is a legal basis for the Cassation Division to review cases settled by state courts in accordance with state laws; if there is a legal backing for such judicial exercise, and whether it is objectionable in principle as well as for pragmatic reasons.

The Cassation Division claims that the practice of cassation over cassation is in conformity with the letter and spirit of the rules defining its jurisdiction. However, the article takes an issue with this practice and argues that Ethiopia ought to preclude its Cassation Division from having cassation over cassation

\footnotetext{
* Lecturer in Law, Faculty of Law, Addis Ababa University

${ }^{1}$ The Federal Constitution of Ethiopia, 1994, Article 83/1, Proc. No. 1 Fed. Neg. Gaz., Year 1 no 1. A final decision means final determination ending entire case in court and leaving nothing further to be done therein except the carrying into effect of such determination by operation of law; one which ends the litigation on merits and leaves nothing for the court to do but execute the judgment. The purpose of the final decision requirement is to disallow any review from any decision which is "tentative, informal or incomplete" So long as matters remain open, unfinished or inconclusive, there is no final decision and therefore non-appeal able since that decision will not adjudicate the rights of the parties. Some decisions on interlocutory matters, however, have the effect of disposing the whole matter because a ruling can refer to final deter-
}

mination of collateral matter, distinct from general subject of litigation, but settling rights of parties to particular issue. A.R. Sedler said: if the effect of a decision is "to adjudicate the rights of the parties in the controversy, the decision constitutes final and is appealable, notwithstanding that some thing more remains to be done.

Another meaning given to the words "final decision" is the exhaustion of appeal available to a given case, meaning "the completion of appeal(s) at the disposal of a given applicant in a given legal system. Thus, a decision constitutes a final judgment where the decision itself finally disposes of the case or/and the decision has completed the possible appeal (s). St. Paul Minn, "Words and Phrases," (Vol. 16A) (West Publishing., 1959) at 210. Samuel Fucherou, "The Organs of Soviet Administration of Justice: Their History and Operation,” (Lei den Co., 1979) at 2. 
for, inter alia, disallowing double cassation would not frustrate the aim of attaining uniform interpretation and application of laws. This option would also be less costly and tends to respect the semi-sovereign power of the regional states ${ }^{2}$. The writer synthesizes the relevant literature, background documents, legal provisions and practice of the Cassation Division as well as the lived experience of other countries, based on which a conclusion follows.

\section{Overview}

The power of the Cassation Division to review final decisions of any federal court is not controversial. ${ }^{3}$ However, whether the power of the Cassation Division to review final decisions of regional courts is backed by legal authority is less clear and invites debate. The power of the Cassation Division in considering a second cassation is not immune from such controversy either. Here, it is aimed to address the ramifications of the question: is the Cassation Division authorized to review final decision on matters assigned to

${ }^{2}$ As per Article 47 of the present Ethiopian Constitution, there are 9 regional states each has its own three tiers of courts. In addition, there are two cities, with their own two levels of courts namely, Addis Ababa and Dire Dawa, administered by the Federal Government. Final decisions flow from all these courts including the federal courts as well as from military courts to the Cassation Division. Cases can flow to the same from the Appellate Court of Municipal Courts; see the Revised Addis Ababa City Administration Charter, 2003, Proc., No. 311, Fed. Nega., Gaz., Year $9^{\text {th }}$ No. 24.

${ }^{3}$ In relation to delegated matters, a second appeal to the Federal Supreme Court should be permissible only when a state Supreme Court has varied or reversed the decision of the State High Court rendered while carrying out its agency; after the second appeal is resorted to in the Federal Supreme Court, a litigant may apply to the Federal Supreme Court for review in Cassation; in case where the state Supreme Court confirms the decision of the State High Court on federal matters, the only remedy left is petition for Cassation to the Federal Supreme Court. In light of this, Article 80(b) of the Constitution should have read: "Decisions rendered by a state Supreme Court on Federal Matters in its first instance or appellate jurisdiction in variation of the decision of the State High Court exercising its delegation are appealeable to the Federal Supreme Court.” Any other construction of Art 80(b) of the Constitution would give a second appeal against decisions on delegated matters which are confirmed by the state supreme courts. Yet such opportunity does not apply to those decisions rendered by the Federal High Court in confirming the decision of the Federal First Instance Court. And this would lead to discrimination between litigants initiating their cases in the state high courts and those initiating their cases in the Federal First Instance Court.

The Oromia Supreme Court renders decisions while exercising the jurisdiction of the Federal High Court and then used to review those decisions in cassation there and then. In addition to undue advantage mentioned above, review of federal matter in state cassation is contrary to the law as the cassation power of the Federal Supreme court is not given to state courts via delegation; it also creates unnecessary issue of compensatory budget. 
the regional courts and what about the power of cassation over cassation? ${ }^{4}$

Two possible opposing arguments can be envisaged ${ }^{5}$. The first argument is that the practice of the Cassation Division is not in congruity with the law; and that this division does not have the power to decide cases relating to regional matters nor does it have the power of cassation over cassation on such matters. The Cassation Division may, for this strand of thought, rightly review cases decided by state supreme and high courts on federal matters delegated to them. This view appeals to the current structure of state and that of courts in Ethiopia and therefore the corresponding horizontal distribution of power between the center and the periphery. The other position is that the practice of the division is in conformity with the spirit and the closer reading of the law defining its jurisdiction. The two positions are examined in the two sections that follow.

\section{Against Federal Review}

The argument aspiring to preclude the Cassation Division from reviewing final decisions of state courts on state matters insists that Article 80[3(a)] of the FDRE Constitution must be read taking its spirit into account. For this constitutional clause suffers from over generalization, the argument goes, it must be qualified to read: the Cassation Division has a power of cassation over any final court decision relating to Federal matters. This Constitution envisages a federal state structure; it also sets out a dual court system. Accordingly, the regions do have their own separate tiers of courts. These regional courts have certain jurisdiction over some matters; over these

\footnotetext{
${ }^{4}$ The term 'cassation' comes from the French verb 'Casser' and its literal meaning is to "quash the force and validity of a judgment. In Ethiopia, cassation may be taken as a means by which a final decision of any lower court - in relation to which appeal is exhausted - containing a basic error of law is reversed or varied by the Cassation Division. See Rene David, "French Law: Its Structure, Style and Method”, (Addis Ababa University Law Library, Unpublished, 1968) at 33. See also Bara Laskin, "The Independence of the Judiciary”,29 Canadian Bar Review (1951) at 1050. The term "cassation" was used in legislation in Ethiopia for the first time in the treaty signed between Ethiopia and France in 1908. Article 7 of this treaty states the Em-

peror had the prerogative to review final decisions of the special courts by way of cassation, i.e., for error of law. A full-blown form of cassation was not created. In Civil Procedure Code of Ethiopia, a variant of cassation called review was incorporated and this Code states that non-appealable decisions of the regular courts including the Imperial Supreme Court would be subject to review by the Zufan Chilot. See Tamiru Wondmagenu, "Fetihe We Rete", 3 Hegawinet 5 (1991)at 65-82.

${ }^{5}$ See infra note no 9 . The argument against federal review of state matters has been raised in some Cassation Division cases on the ground of lack of jurisdiction; but such argument has not been forcefully pursued either by academics and practicing lawyers.
} 
matters, they must have a final say; the federal courts must not review, be it by way of appeal or cassation, over matters squarely falling within the ambit of state courts.

Nevertheless, the structure of a state does not necessarily show the structure of the court in that state and the Ethiopian Federal State has organized a modified form of dual court structure. Nwabueze stated: "if the federal principle were to be strictly applied one would expect a dual system to be established in a federation, one set of courts to apply and interpret the law of the central government, and other to apply and interpret the law of each state" 6 . Since this is not always the case, the assertion that there is a direct correlation between the court structure and that of the state may not always be correct. Thus, it will not be illogical to say that a federal state may or may not establish a federal court structure.

In Germany, for instance, there is no system of dual courts of the federation and the Lander ${ }^{7}$. The same is true for Canada, since there is an indication that appeal is lodged to the Supreme Court only from provincial courts ${ }^{8}$. Therefore, a federal state may adhere either to the dual court structure where each of the units, on the one hand, and the federal government, on the other, has its own stratified court structure or to the establishment of only a supreme court for the central government and other courts of the units which are independent by themselves but dependent in relation to the jurisdiction of the national supreme court. The dual court system is best characterized by the existence not only of a federal supreme court but also subordinate federal courts.

Besides, this line of argument has other reasons, which essentially center on the ground of constitutionality. One is that Article 50(2) of the current Ethiopian Constitution, inter alias, states that "the Federal Government is composed of the executive, the legislative and judiciary; the latter organ specifically the Cassation Division of the Federal Supreme Court contravenes this constitutional provision by reviewing disputes of purely regional nature". In other words, following a federal court structure in the country, the states do have their own separate tiers of courts with certain jurisdiction over some matters which could be identified by way of inferences; over these matters, regional courts must have a final say; and the federal courts must not review, be it by way of appeal or cassation, over matters squarely falling within the

\footnotetext{
${ }^{6}$ B.O. Nwabueze, "The Machinery of Justice in Nigeria”, (Butterworth, 1963) at 82

7 David Morris, “Judicial Process”, (Pitman Publishing Co., 1992) at 50

8 David Currie, "Federal Courts” (West Publishing Company, 1968) at 51
} 
ambit of state courts. Therefore, this argument urges us to read the words "...any court..." in Art $80(3$, a) of the present Constitution as "any federal court or any other court rendering a final decision on federal matters." Secondly, this action of the Cassation Division also violates another constitutional stipulation, that is, Article 80(2), which states that state supreme courts shall have the final judicial power over state matters. Since the action of the Cassation Division distorts the system of courts envisaged by the Constitution, the division should reject any petition relating to a matter assigned to state courts on the ground of lack of authority. ${ }^{9}$

Another reason in support of those who oppose federal review of state court decision comes from a combined reading of Article 80 (3a) of the Constitution and Article 10 of the Federal Courts Proclamation. The former provision does not provide in an explicit manner that final decisions of state courts on state issues are subject to cassation review at the federal level. The provision simply states that the particulars shall be provided for in a subordinate legislation. The subsidiary statute that has been enacted, among others, to implement this constitutional issue is the Federal Courts Proclamation, which also fails to expressly provide federal revision of state court decisions on state matters. In particular, Article 10 (3) of the Federal Courts Proclamation states that the Cassation Division shall review "final decisions of the Regional Supreme Court rendered as a regular division or in its appellate jurisdiction."10 Yet it is not clear whether this stipulation relates to delegated matters or state matters.

What is suggested here is a qualified reading of Article 10(3) of the Federal Courts Proclamation, which works out the details of Article 80 of the Constitution under consideration by (inter alia) vesting in the Federal Su-

${ }^{9}$ On several occasions, respondents have raised the argument that the Cassation division does not have the jurisdiction to review cases relating to state matters where the states are given the power to make and implement the laws and adjudicate cases under the Federal Constitution . To wit: in W/ro Felekch Alemu V. Debay Woldemeskele, Federal Supreme Court, Civil File No 181/1999 (Unpublished), the respondent argued that the Cassation Division did not have the authority to review the matter, which was a dispute over the ownership of a given building litigated in the Supreme Court of Southern Nations, Nationalities and
Peoples. The judges rejected the claim reasoning that: "The Court has the power to review federal or state court final decision so long as such decision contains a basic error of law as stated in Article 80 (3. a) of the Constitution and Article 10 (3) of the Federal Courts Proclamation. And that in regions where supreme courts exercise their cassation power, final decision means the decision of such cassation divisions and in regions where supreme courts do not exercise cassation power, final decision means a non-appelable decision of any level of courts in the same”

${ }^{10} \mathrm{Id}$. 
preme Court the power of cassation over "final decisions of the Regional Supreme Court rendered as a regular division or in its appellate jurisdiction". This stipulation of ancillary legislation may only allow certain inferences. Accordingly, the Federal Supreme Court has cassation power either over:

(a) those federal matters decided by a state supreme court in its first instance jurisdiction, i.e., over the jurisdiction of Federal High Court delegated to state supreme court, or

(b) those federal matters decided by a state supreme court in its appellate jurisdiction, i.e., on matters falling under the jurisdiction of the Federal First Instance Court yet delegated to the state high courts.

This formulation is not without an antecedent. As per Article 12(1) of the Central Courts Proclamation (which corresponds with Article 10(3) of the Federal Courts Proclamation, "the Central Supreme Court could hear final decisions of the National/Regional Supreme Court made on the basis of the Charter, International Treaties or Laws of the Central Government on matters of right, freedom or interest...." This obviously implies that if a regional supreme court renders a final decision by applying a regional law, then the Central Supreme Court would not have cassation power over that decision. Moreover, Article 3 (1) of the Federal Courts Proclamation provides that "Federal Courts shall have jurisdiction over cases arising under the Constitution, Federal Laws and International Treaties."

The argument in favor of federal review of state matters by cassation is not without merit. Seen from the point of view of the Cassation Division, it lessens its burden since several petitions come from regions ${ }^{11}$, and since the argument under consideration requests the division to reject these applications for lack of jurisdiction. A petition for cassation has to be first examined by three judges of the Federal Supreme Court ${ }^{12}$. These judges have to go through the petition of the applicant wherein she must indicate as to why she alleges that the decision of the lower court contains a basic error of law ${ }^{13}$.

\footnotetext{
${ }^{11}$ As the record of the Cassation Division indicates, half of the applications filed since Jan. 1993 came from the regions. Petitions are referred to the Cassation Division after three judges make a prior ruling as to the existence of a basic error of law. These cases are: final decisions of the Federal High Court rendered in its appellate jurisdiction; the appellate jurisdiction of the Federal Supreme Court and the Regional Supreme Court. The author was told by the Registrar of the Oromia Supreme Court that

about 5, 000 applications for cassation were filed between September 2003 and April 2005 some of which would end up with the Cassation Division for second cassation.

12 Petitions are referred to the Cassation Division only after three judges make a prior ruling as to the existence of basic error of law. These cases are: final decisions of the Federal High Court rendered in its appellate jurisdiction; the appellate jurisdiction of the Federal Supreme Court and the Regional Supreme Court.
} 
These judges are also expected to go through copies of the contested final decision and through decisions of some other lower court, if any ${ }^{14}$ It is only after having gone through all of these documents and having summarized the facts of the case and having identified the possible issues that the three judges are expected to respond either positively or negatively. It is needless to mention that this process requires money, energy and above all precious judicial time.

From the point of view of a respondent, this view is advantageous too for it minimizes cost and inconvenience and gives him/her an opportunity to insist on execution of the final decision ${ }^{15}$. Lastly, this view assigns a final say to the regional states over their affairs. For these reasons, the author suggests that the authority of the Cassation Division should be limited to the powers that was accorded to the Cassation Division of the Central Supreme Court of Ethiopia, i.e., between January $11^{\text {th }} 1993$ and $15^{\text {th }}$ February 1996; The Division had the power to review matters of the Central Government or cases that raised the concern of the Central Government. In particular, the Division could examine, among others, final decisions of the National/Regional Supreme Court made on the basis of the Charter, International Treaties or Laws of the Central Government on matters of rights, freedom or interests

${ }^{13}$ Federal Courts Proclamation, 1996, Article 22, Proc. No 25, Fed. Nega. Gaz., Year 2 No 13.

${ }^{14} I d$. The author learned from the Registrar of the Federal Supreme Court that between July 2004 and April 2005, closer to 2000 application for cassation were filed.

15 See the Oromia National State Courts Proc., 1995, Article, Proc. No. 6 Megleta Oromia Year 1 No.6 As per this article, when a case is confirmed by the first appellate court, there is no second appeal; a second appeal lies when the first appellate court renders a decision at variance with the first instance court. For example, the Oromia State has four tiers of courts. In ascending order: the Social Courts, District Courts, the Zonal Courts and Supreme Court. This State also has a cassation review within its Supreme Court. Suppose X initiated a case against Ato $\mathrm{Y}$ in one of the social courts. The same person lodged her appeal to a district court since she lost the case. The latter court reversed the case, deciding in favor of $\mathrm{X}$, Ato $\mathrm{Y}$ has filed his appeal to the high court in the region. The high court confirmed the decision of the district court. Now since a third appeal is not permissible in Oromia National Regional State, Ato $\mathrm{Y}$ is left only with review by way of cassation in the State. Suppose again, the Oromia National Regional Supreme Court ruled that the decision did not have a basic error of law. Since the argument in question forbids Ato $\mathrm{Y}$ to file a second cassation to the Federal Supreme Court, X could safely initiate execution proceedings. If we, however, argue that Ato Y has the right to lodge a second cassation, then undesirable consequences may ensue. If we assume $\mathrm{X}$ lives in the remotest part of the country, she would experience inconveniences since she might be required to come to Addis Ababa where the Cassation Division sits unless, in some cases, the Cassation Division conducts a hearing through a video conferencing. Still in the latter case, the respondent has to come to the seat of the Regional Supreme Court to be access the technology. 
concerning regional cases. ${ }^{16}$ (emphasis added)

\section{For Federal Review}

The other position on the issue at hand is that the Cassation Division has the power to review any final court decision, be it on federal or regional matters. Although Article 80[3(b)] of the FDRE Constitution and some regional proclamations ${ }^{17}$ envisage the establishment of a cassation division within the supreme courts of each state, some states such as the Amhara National Regional State and the Somali State have not established such a division. Despite this, some regional supreme courts do have first instance jurisdiction.

The Amhara National Regional State Supreme Court, for example, does have first instance jurisdiction, inter alia, over offenses for which officials of the regional government are held liable in connection with their official responsibility $^{18}$. Assuming that the corresponding civil litigation is supposed to take place in the regional state supreme court and if we insist on the idea that the Cassation Division should not have any review power over regional matters, in the absence of a functional cassation division in the regions with a supreme court possessing original jurisdiction, then the right of citizens in such regions to seek for review of their cases would be prejudiced. In this context, it is thus plausible to hold that, at least for the time being, the Cassation Division should have some review power on state matters ${ }^{19}$.

Some also say that since a federal system is a new experience to Ethiopia and because the regions do not have a well-developed judiciary, it is judicious to confer on the Cassation Division the power to review state matters ${ }^{20}$. However, the capacity and the competence of the state courts cannot be in principle justify cassation at the center. Remedial measures against the weak-

\footnotetext{
16 See the Central Government Courts ${ }^{20}$ Abebe Mulatu, “Apportionment of JurisdicEstablishment Proclamation, 1993, Art 12/1, tion under the 1994 Ethiopian Constitution”, Proc. No. 40, Nega. Gaz., Year 52 No 25.

${ }^{17}$ See Southern Nations, Nationalities and Peoples State Courts, 1996, Proc. No. Debub Nega. Gaz., year 23 no 6.

${ }^{18}$ State supreme courts have already started invoking their original jurisdictions; an example is the trial of ex-President of the Somalia National State in the Supreme Court of the same.

${ }^{19}$ The author believes that the appropriate long-term solution to these cases should be to move the original jurisdiction of the state supreme courts of such regional states to Symposium Proceedings, (Ethiopian Civil Service College, 2000) at 150. He argues that without cassation over state matters the federal government will not be in a position to implement or interpret its laws uniformly since most of the cases that arise from federal law are within the exclusive jurisdiction of state courts as the current practices show. He argues also that subject-matter dichotomy between state-versus-federal matters shall be disregarded and all cases shall be decided by state courts with review by the Federal Supreme Court.
} 
nesses and inadequacy of resources encountered by the state courts (rather than central supervision and control) are obviously the most appropriate options. Besides, one may wonder whether judicial power is more serious than the legislative or executive exercise that is bestowed upon the states by the Federal Constitution.

Literal construction of the relevant law is also advanced in support of federal review of state matters. There is this rule of interpretation, which requires us not to seek for an interpretation when a given legal rule is clear ${ }^{21}$. One may thus adhere to the literal reading of Article 80[3(a)] of FDRE Constitution which provides that "The Federal Supreme Court has a power of cassation over any final court decision...”. In other words, the provisions means what it means; and the Cassation Division has the power to review all final decisions rendered by any court throughout the country.

There is yet another canon of construction ${ }^{22}$, which urges us to read any legal provision contextually. Read together, the sub-clauses of Article 80 of the Constitution give us this message: in principle, the Federal Supreme Court and State Supreme Courts do have the highest and final judicial power over federal matters and state matters, respectively. After stating this general rule, sub-article [3(a)] of the same article, partly, provides: "Not withstanding the provisions of sub-Articles 1 and 2 of this Article: (a) the Federal Supreme Court has a power of cassation over any final court decision (Emphasis added). From this, we can deduce that the special remedy of cassation is an exception in the sense that even if state supreme courts are recognized to have a final say over state matters, review in cassation by the Cassation Division in respect of state matters is also permitted.

Reference to the Minutes of the Constitutional Assembly reinforces this line of argument. Initially, the Committee, assigned to work on matters related to the structure and organization of courts had come came up with a sub-article, which only conferred cassation power upon the Federal Supreme Court, without conferring similar power upon state supreme courts. Later on, however, the Committee proposed that a similar power be accorded to State Supreme Courts: ${ }^{23}$

The Committee assigned to work on the structure and powers of courts formulated Article 80 of the Draft Constitution to give the power of review by cassation to the Federal Supreme Court alone. This draft article

\footnotetext{
${ }^{21}$ George Krzeczwnowicz, “An Introductory ${ }^{22}$ Id. p.5

Theory of Laws in the Context of the Ethio- ${ }^{23}$ The Minutes of the Constitutional Assempian Legal System”, (Addis Ababa Univer- bly of the present Ethiopian Constitution No sity Law Library, unpublished, 1971/2) at 4. 26-29, (Unpublished, 1993) at 34-36.
} 
does not accord state courts with similar power. Later on, the Committee deliberated on the wisdom of conferring cassation power upon state courts and recommended for its incorporation in the Constitution to the Constitutional Assembly.

The Constitutional Assembly accepted the idea that the Cassation Division can also review a final decision reviewed through cassation by state supreme courts $^{24}$ :

The cassation division of the Federal Supreme Court shall have cassation power over not only federal matters but also over state matters even if state supreme courts have already reviewed such matters in cassation. A party to a case based on state law and decided by a subordinate state court may opt for review by way of cassation in his/her state supreme court (if there is a cassation division) and if he/she still thinks that the basic error of law is not rectified he/she can submit her/his case to Federal Supreme Court.

However, the Constitutional Assembly did not express this idea accurately in the draft document for Article 80[3(a)] which does not explicitly point out whether the Federal Supreme Court assumes cassation power over both federal matters and state matters. This draft sub-article runs in part ${ }^{25}$ : “The Federal Supreme Court shall have cassation power over any final decision rendered by a state court containing a fundamental error of law”. However, given the ideas reflected in the Minutes of the Constitutional Assembly, it would be a disservice to the intention of the framers if we read this draft subarticle in such a way that it would not give cassation power to the Federal Supreme Court on state matters.

For the framers of the Constitution, the main reason for the existence of cassation in the states seems to be to minimize the workload of the Cassation Division $^{26}$ : “... the existence and operation of a cassation division within state supreme courts can have the effect of reducing the workload of the Federal Cassation Division..." Putting review through cassation in state supreme courts in place does not necessarily minimize case backlog in the Cassation Division. A party who has lost a case in state cassation will be tempted to file a second cassation in the Federal Supreme Court. At least the losing party might somehow try to use the opportunity to file a second cassation as a strategy to delay the execution of the final decision.

\footnotetext{
${ }^{24}$ Id. p.43

${ }^{25}$ See the Minutes of the Council of Representatives of the Transitional 
The second reason advanced by the drafters of the Constitution to go for state cassation is disposition of disputes correctly ${ }^{27}$ : “... besides, the establishment of cassation division within state supreme courts may lead to the correct disposition of cases...". The connotation of this statement may mean that the existence of a double cassation is better in helping the country rectify an erroneous decision than is the case of a single cassation. It is not unsound to assume that the mere presence of a federal review of state matters by way of cassation can force state supreme court judges to take care in handling cassation petitions. Yet, the existence of double cassation may not necessarily lead to the correction settlement of cases.

The third factor the framers had in mind was the need to have a uniform interpretation of laws throughout the country ${ }^{28}$ :

...The wisdom of and necessity of having a cassation division within the Federal Supreme Court is to accomplish the goal of having a uniform interpretation of laws-federal or regional-throughout the country. To this end, any final court decision in this country shall be reviewed by the Federal Cassation Division provided it contains a fundamental error of law.

This third rational for the existence of double cassation should be partly true since Ethiopia has adopted a federal form of state and since federalism is believed to promote unity in diversity. It appears that the essence of the preamble of the Constitution is that communities in this country are the same in some respects and are distinct in some other respects. In the latter cases, distinctiveness shall be maintained, among others, via law making and interpretation. It is not desired that homogeneity shall be expected in areas where diversity is expected. Consequently, each state is expected to promulgate its own law in line with its cultural values.

The words "to have a uniform interpretation of laws throughout the country" in the minutes cited above are so inapt that they might contribute to the suppression of the diversity, which will inevitably be reflected in various regional laws. Hence, given the ideals of the present Constitution of Ethiopia, by way of review in cassation, it is not desirable to promote the uniform construction and application of law throughout the federation. A regional cassation may be expected to bring about uniform and correct construction of regional laws while the federal cassation should be there to promote uniform interpretation of federal laws. Switzerland, USA and Argentina have, in their respective national supreme courts, an extraordinary appeal that is limited to

${ }^{27} \mathrm{Id} \quad{ }^{28} \mathrm{Id}$


the interpretation of federal rules and whose purpose is to achieve and maintain uniform application of federal laws ${ }^{29}$.

As the law stands, there is cassation over cassation on matters falling within the ambit of state courts where a given state has in fact established review in cassation. On the other hand, where a given regional supreme court does not have a cassation division in place, there is only one cassation. In relation to federal matters, there is and should be a single cassation. This is a proper appreciation of the intention of the framers which can also be substantiated by closer scrutiny of the provisions relating to the cassation powers of the Ethiopian Federal Supreme Court. The framers of the present Ethiopian Constitution claimed to have chosen the larger societal goal behind the institution of cassation at the federal level at the expense of the cost of proceedings and judicial autonomy of the regional states. Thus, the arguments advanced against the review of state matters in federal cassation should not be seen as arguments lex lata (based on the law as it currently is) but arguments de lege ferenda (the law as it ought to be).

\section{Towards Legislative Amendment}

As the law stands, the Cassation Division has the power to review final decisions not only on federal matters but also on state matters ${ }^{30}$. It is thus the conclusion of the previous part of this article that the Cassation Division, as the law describing its jurisdiction stands, possesses the power to handle any justiceable matter disposed by any court in a country on the proviso that such decision is final and contains basic error of law. The parallel court system thus converges at the apex; Ethiopia has established semi-centralized judicial system. The Ethiopian present court structure therefore depicts a unique

\footnotetext{
${ }^{29}$ See Supra Note 4, Charles Platto, at 333. In Switzerland, for instance, the Cassation Court, steps in where the court below: incorrectly applied Cantonal law instead of applying federal laws or failed to apply the system of foreign law called for by Swiss conflict of rules or failed to ascertain the contents of the foreign law to be applied or violated provisions of federal law (including treaties) concerning jurisdiction.

${ }^{30}$ Unlike the other divisions of the Federal Supreme Court, the Cassation Division dwells upon all sorts of cases, civil, labor and criminal. As opposed to the other

divisions, the Cassation Division can entertain cases coming from military courts. See Defense Forces Proclamation, 1996, Article 26, Proc. no. 27 Fed. Neg. Gaz year 2 no 13. See also Yoseph G/Egzahbeher, "The Hearing of Final Judgment by the Supreme Court by Way of Cassation”, $\underline{14}$ JEL1, (1988) at 161. Finally, the other divisions are relatively more permanent than the Cassation Division in the sense that the Supreme Court constitutes this division when, among others, three judges refer a case to it. And thus, judges are not assigned for the sole purpose of making review through cassation.
} 
feature: it is not a dual court system (e.g. USA) pure and simple. Nor is it the same as those federal states having only federal supreme courts but without federal subordinate courts (as in Germany). ${ }^{31}$ The Ethiopian cassation regime lies between the two.

Various undesirable consequences may follow from the existence of cassation over cassation in addition to the pitfalls of a single cassation at the center on state matters: delay, inconvenience and expense given the size of the country and the different working languages of state courts, court congestion and the tendency of judicial centralization. ${ }^{32}$ As an illustration, in one case, the disputants were spouses ${ }^{33}$. Upon the dissolution of their marriage, family arbitrators decided that the respondent should take two-thirds of the common property since the applicant had committed bigamy. The dispute arose in Eastern Welega (in Oromia State). The applicant lodged his appeal in a Wereda Court (the lowest court), then in a zonal court, and again in the Oromia Supreme Court followed by petition for cassation in the Cassation Division of the same and finally in the Federal Supreme Court Cassation Division. A series of appeals and cassation may also appear in the execution proceedings of the same case. This is objectionable on pragmatic grounds than any commitment to the dual court system.

The legislature has three options. Option one is to maintain the status quo; the Cassation Division keeps on reviewing state supreme court decisions over state matters even if that state has a functioning cassation division. Option two is to preclude the Cassation Division from exercising jurisdiction over regional matters where a given state has, in fact, established a cassation division within its supreme court and to allow the Cassation Division to entertain application relating to regional matters where such state does not have review in cassation. In the second alternative, the Cassation Division will cease to entertain application from a given state matters when the latter establishes its own cassation division. The gradual abolition of the review of state court decision in relation to state affairs is a suspect even with a sun set clause. In a country like Ethiopia which is heavily encumbered with a long history of centralization, a gradual relinquishment of authority on the part of the Fed-

\footnotetext{
${ }^{31}$ Daniel J. Meador, “American Courts”, (West Publishing Co., 1991) at 28

${ }^{32}$ Court congestion in itself cannot be raised as aground against granting the Cassation Division the power of reviewing state matters such problem is generic in the sense that it could occur in any appellate court reviewing a decision of lower court. See Yonatan

Tesfaye, "The Federal System and the Courts: Federal Supreme Court Reviewing State Matters", 2 Society of Law Students for Quality Education1 (Feb. 2000) at 29.

${ }^{33}$ Regassa Chali V. W/ro Werke Kimosa, Federal Supreme Court, 1998, Civil Petition No. 29/98 (unpublished).
} 
eral Supreme Court is less convincing. The third option is to take away the power of the Cassation Division over state matters immediately and unconditionally. The author would go for the third option. Eliminating review of state matters, on the top of saving cost, energy and above all precious judicial time, would not abort the aim of attaining the uniform and correct interpretation of regional laws since the current Constitution itself envisages the establishment of review through cassation in the states themselves.

On the top of pragmatic considerations, a desire to respect the semi-sovereign power of the regional states should be mentioned. In a federal state such as Ethiopia, uniform construction and application of laws throughout the country is not expected when it comes to the laws of the units which are expected to be applied uniformly only in the concerned state via state cassations. The current FDRE Constitution has clearly apportioned legislative and executive power to the regional states, and there is no compelling reason to record a reservation when it comes to judicial power. The states should thus be allowed to experiment on judicial power, by allowing them to interpret and apply the laws issued by their respective state councils. The existence of the same political party in several of the regional states at present with its effect of a striking similarity in policy and law in the two planes of the federation should not be a reason for maintaining double cassation.

\section{Conclusion}

The Cassation Division, located at the apex of the present court system in Ethiopia, is a judicial unit of last resort. It considers any final court decision over any matter, whether federal or regional and regardless of the tier of the court $^{34}$, provided such decision contains a basic error of law. If one takes, as the Cassation Division does at present, the finality test to mean even decision over state matters except cases that invite constitutional interpretation, the reach of state power depends on what the organ of the federal government determines to be a proper excise. This federal organ then can decide what the state government can do and cannot do through its power of interpreting the laws. The authority of the Cassation Division over state matters is not

\footnotetext{
${ }^{34}$ Cases can be filed to the Cassation Division directly from a Woreda court if the decision under the law is final. For example, land disputes in the Oromia National Regional State are handled by the Social Courts whose decision can be appealed to the Woreda courts whose decision are final and can be ripe for cassation. Another example: in a case where the issue of bail is submitted to and granted by a first instance court; since that decision is final if the public prosecutor is not satisfied with the grant of bail, he can lodge a petition for cassation not an appeal. See Article 74 of the Ethiopian Criminal Procedure Code of 1965. For a similar example see Article 197 of the same in respect of default judgment.
} 
desirable resource-wise and seen in light of the ends of cassation and federalism. Nor does its authority rest on unambiguous rules precisely because such authority is susceptible to interpretation. 